
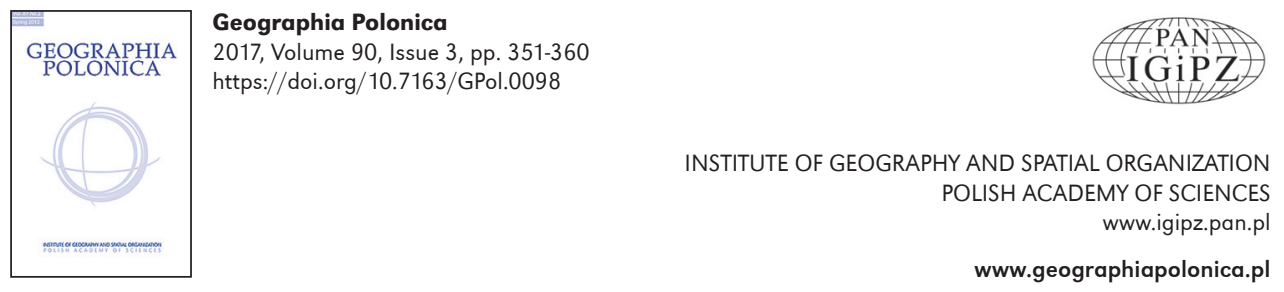

\title{
EXTERNAL MIGRATION IN THE PRESHEVA VALLEY: CAUSES, BENEFITS AND CONSEQUENCES
}

\author{
Arsim Ejupi \\ Department of Geography, Faculty of Mathematical and Natural Sciences \\ University of Prishtina \\ George Bush, street, n.n., 10 000, Prishtina: Kosovo \\ e-mail: arsim.ejupi@uni-pr.edu
}

\begin{abstract}
Migration in the Presheva Valley is an integral part of the past and present, affected by social and historical processes, which also have demographic, social, economic and cultural consequences. The Presheva Valley, similar to other territories of the former Yugoslavia, is distinguished by low economic development and this phenomenon has been present through decades. As such, the Presheva Valley is traditionally a migrant area. Backwardness in economic and infrastructural development causes many problems of a social and economic nature, while permanent growth of the absolute and relative number of people is manifested by an increase in the number of the agricultural population, fragmentation of agricultural land, etc. All these circumstances force the population to migrate and find work in European countries. The aim of the research is to identify factors which stimulate migration, to analyze the period, causes and directions of migration, the negative effects of migration as well as benefits for the migrant's homeland. The study offers an overview of current migration trends and it could serve as a good basis for regional policymakers in the field of migration with the final goal of interrupting the regressive social and demographic processes and accelerate economic development.
\end{abstract}

\section{Key words}

Presheva Valley - population - migration - labor force Europe

\section{Introduction}

Migration is a dynamic phenomenon involving many twists and turns. Driven by a multitude of possible reasons, migrants may move temporarily or permanently, transnationally and nationally, individually or in groups, return to their countries of origin or migrate to another country, or move between two or more countries in a circular manner (Kahanec \& Zimmermann 2008). Migration of the population represents a multidimensional phenomenon 
caused by a variety of factors, often intertwined and mutually connected. Each period of social development of humans was associated with migration of different types, with special causes and consequences, in different directions and territorial distances, with a different level of intensity, integration and assimilation of migrants. Migration movements cause numerous transformations in demographic, social, economic and political terms (Islami 2005). The establishment of settlements, changes in their size, including their total abandonment, and the demographic characteristics of mobility, among other factors, were and have remained under the strong influence of migration (Islami 1984). All the above facts argue for the importance of migrations; therefore they deserve special attention.

The Presheva Valley is located in the central part of the Balkan Peninsula, more precisely between the Morava Valley in the north and
Vardar Valley in the south (Fig. 1). These two valleys constitute the most important natural corridor which connects Europe with South East Europe, the Middle East and Northern Africa (Ejupi and Ramadani 2016). It covers a territory of $1,250 \mathrm{~km}^{2}$, with an Albanian population of around 100,000 , who currently make up around 80 per cent of the region's population. The Valley was and remains the most underdeveloped region in Serbia and the Balkans: the Albanian-inhabited areas are more than 7 times less developed than the average of Serbia (Ejupi 2013).

\section{Theoretical background}

There have been many attempts to explain the phenomenon of migration based on general migration theories and the specific conditions for the particular region as well. If we take a look at the push and pull factors of migration,

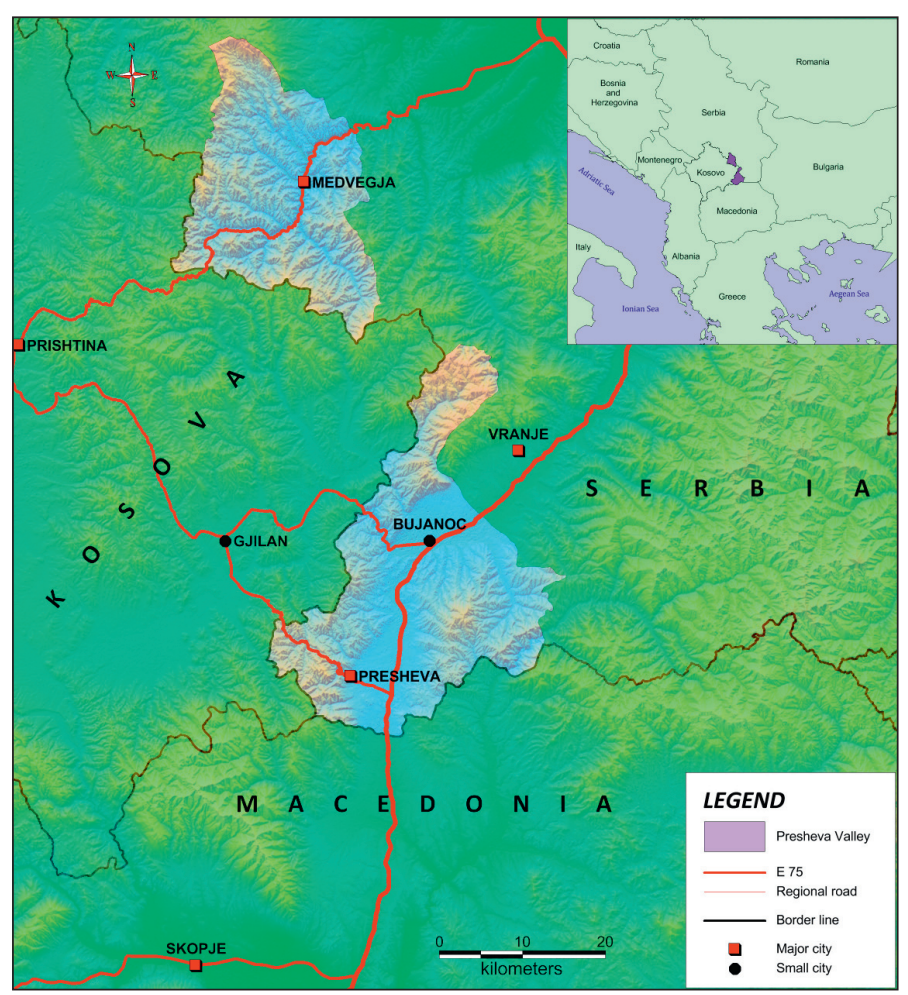

Figure 1. Geographical position of the Presheva Valley Source: Ejupi \& Ramadani 2016. 
it is clear that during the wars that happened in the Western Balkan countries, the main cause for migration was war and conflict. But it is obvious that during peaceful times the main causes for migration are poverty, insufficient income, looking for better living conditions, better social welfare, etc. Çaro and van Wissen (2007) explain the process of emigration within the context of transformation. They observed that transformation from a centralized communist, planned and inefficient economy to a modern competitive economy fuelled emigration both in terms of opportunities (pull factors) and push factors (transition-related temporary economic deterioration). The theoretical statements above are in line with the situation of migration in the Presheva Valley which has passed through armed conflict and in the meantime, as part of former Yugoslavia during the 1990s, has experienced the transformation of the political and economic system.

One of the most important types of migration is external migration taking place between countries, then within continents and between continents. External migrations have a long history, are much more complex than internal migrations and are the most expensive; they are developed over long distances and carry various uncertainties and risks (Sauvy 1966). Islami (2012) noted that these migrations have intensified in recent times, when the migration of ethnic, racial and linguistic communities has escalated and the ethnic and demographic composition of the oikoumena ${ }^{1}$ has experienced major changes.

Mass movements for the purpose of 'temporary employment' from the area of former Yugoslavia started in the early 1960s. In the search for employment, a number of workers went to Western European countries, while the number of migrants leaving for overseas countries decreased. Migrants from Yugoslavia took an increasing role in the European economy which needed additional labor (Vuković 2005).

Grečić et al. (2007) noted that during the 1990 s and into early 2000, the step-by-step

\footnotetext{
${ }^{1}$ Inhabited cities.
}

disintegration process of the former federal state of Yugoslavia was the main factor influencing waves of migration. The authors mentioned above enumerate three categories of push factors: economic, political and ethnic, all of which are directly linked to the disintegration process. If we compare push and pull factors of migration, it is clear that during the disintegration, conflicts and wars in former Yugoslavia, the obvious reason for migration was to survive life-threatening conditions. However, in peaceful times the main reason for emigration is poverty, in particular lack of or insufficiency of income (Kupiszewski et al. 2009). Since the Presheva Valley continues to be part of Serbia which was part of the former Yugoslavia, all the above mentioned factors have caused migration from the region as well. From the research literature it is clearly seen that there is a lack of scientific research regarding migration from the Presheva Valley.

The population of the Presheva Valley is mainly rural. It has a patriarchal mentality linked to extensive agriculture, with many of the social functions being performed within the household and village. This has produced very low spatial and social mobility. This mobility has included migration of a local character within the municipality of the same village or to neighboring municipalities mainly by changing place of residence, marriage, etc.

Also there was displacement of the population from the mountainous villages of Karadag, with their unfavorable conditions, into large settlements on the plains of the Presheva Valley, but also towards of Anamorava in Kosovo as well as towards Macedonia. However, the high percentage of the autochthonous population shows limited spatial and social mobility.

According to the 1971 census, more than $71 \%$, of the population had not moved, that is an indicator of very low social and spatial mobility, while the immigrant population constituted more than $28 \%$ of the total. It seems that at least three factors have contributed to this.

Firstly, the lack of tradition of social and spatial mobility of the labor force of the population to foreign countries. The exception is migration to Turkey before and after World 
War II because it was conditioned by the political pressures and the process took the form of the migration of entire families rather than individuals. The Albanian labor force, before and after the war, had gone into exile in different centers of the former Yugoslavia, primarily in Belgrade, to provide means of support for their families.

Krasnići (1963) noted that the employment of some Kosovo Albanians and other ethnic groups abroad, for example in Turkey before 1912, in Thessaloniki and, less frequently, in America, did not have any significance in the creation of a tradition of external migration because it was limited to specific professions, such as jewelers, gardeners, shepherds, and confectionery makers (cakes, lemonade, ice cream, etc.). On the other hand, the employment was not oriented towards developed European countries, like Germany, Switzerland, Benelux and the Nordic countries, France, Italy, etc., where the area's labor force migrants of these past five decades have settled, but in Turkey, Greece, Bulgaria, Croatia, Dalmatia, etc.

Secondly, there was a lack of information on the possibilities, advantages, disadvantages, methods of employment, and other details associated with economic migration. In the case of this area, this is related to the first factor of course. It is known that people go abroad from areas that are open to the world through information on the 'external world'. This raises their awareness about the possibilities of going and then of other advantages in the foreign country.

Thirdly, there is the late inclusion of Kosovo employment services as mediators of employment abroad. The employment service in the Valley, within its own quota in Serbia through its own municipal employment institution, only began to operate after 1968 when the process of mass emigration to labor importing countries began.

After World War II the Yugoslav state followed a more moderate and liberal path of socialism compared with other socialist countries, which enabled the free movement of goods and people with the capitalist countries of Western Europe. On the other hand, in many Western European countries, there was an increased need for a labor force to implement projects in infrastructure, industry and house construction. This makes the late 1960s and early 1970s a new-age for the population to migrate as a labor force in many countries of Western Europe.

Due to the worsening economic and political circumstances, migration of the population towards European countries not only continued, but intensified in the following decades. To date, according to the municipalities of Presheva, Bujanoci and Medvegja, the migrating population has reached 23,900 inhabitants or $21.2 \%$ of the total population of the Presheva Valley.

\section{Methods}

In order to achieve the scientific goals, combined geostatistical and empirical research methods were used in this paper. We have used census data from 1971 and 2002 to examine changes in the resident and migrant population. To clarify trends and the main features of external migration, like the age of the migrants, direction, causes, consequences and benefits of migration, it was necessary to conduct empirical research. A survey was conducted within a one month period from July 17 to August 17, 2014. This is the period when most of migrants spent their vacations in their homeland. The present sample survey included 150 migrants from many rural settlements as well as from the urban centers of the Presheva Valley. The survey was conducted through direct contact with respondents, getting reliable information which is anticipated to reflect on various aspects of external migration from the valley.

For the successful implementation of the survey the sample size was determined, which includes $10 \%$ of the households that live abroad. Most respondents were heads of family, but the survey also includes migrants who by age and period of migration, belong to the middle generation. The questionnaire contains many research questions 
(indicators) and is divided into 5 parts. The first part of the questionnaire contains questions of a general nature, like year and place of birth, age of migrants, etc. The second part contains questions dealing with the year and place of migration. The third part of the questionnaire is focused on the causes of migration; the fourth part deals with the consequences and the fifth part deals with benefits for their homeland. The data collected were processed using SPSS (Statistical Package for the Social Sciences) techniques. We considered that empirical research and census data analyses are the most appropriate method to analyze and clarify external migration trends in the Presheva Valley. However there are some shortcomings of the questionnaire because respondents are limited in their answers and there is the possibility of nonobjective answers, especially those that are related to monthly incomes, integration and other difficulties.

\section{Results and discussion}

Since the primary objective of the research was to shed light on modern trends in the population of the territory via research conducted through a survey, there is an emphasis restricted to migrations that took place after World War II towards the developed countries of Western Europe. Due to the transformation of the homogeneous social and economic structure, as well as the regional disparities in terms of economic development in the decades following World War II, an intensification of spatial and social mobility was introduced, as a result of which, according to the 2002 census, nearly half of the population no longer lives in their birthplace (see Fig. 2). ${ }^{2}$

Migration from Southeast European countries often takes place towards the countries of Western and Central Europe like Switzerland, Germany, Austria, mainly because of social and historical relations with those

\footnotetext{
${ }^{2}$ Data for 2002 regarding population abroad were provided from municipality bodies. Data from survey conducted from July 17 to August 17, 2014.
}

countries (Fassmann 2015). This conclusion also applied to migrations from the Presheva Valley.

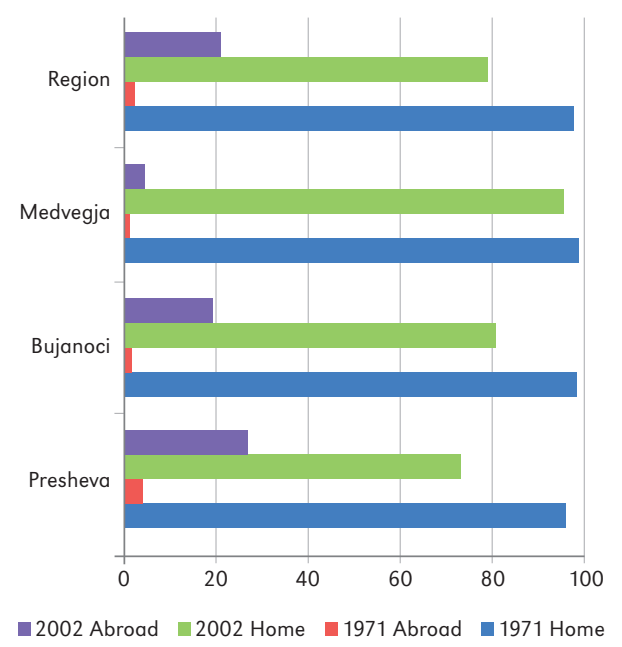

Figure 2. Population of the Presheva Valley (home and abroad) in \%

\section{Period of migration}

By analyzing the data collected with regard to questions about the year of migration it can be seen that $2 \%$ of the population migrated to foreign countries in the period 1965-1970. This simultaneously represents the initial period of migration when for the first time employment offices presented the possibility of going and finding work abroad. Rapid employment, high labor prices and other social and health benefits began to attract many young people who began to migrate towards western European countries in large numbers. Therefore about $14 \%$ of migrants from the valley migrated during the period 1971-1981, while the largest number of those who migrated from the region (39\%) migrated in the period 1981 1990 (Fig. 3).

During the first and second period, only heads of families migrated, while in the late 1980s, entire families begin to migrate or there are different forms of family reunification. In the period up to the late 1970s the causes of migration were primarily economic, while from 1981 onwards, migrations were 
driven by political reasons as well, so as a result this is the period with the highest percentage of the population migrating abroad. This is the period which marks the beginning of the disintegration of the former Yugoslavia.

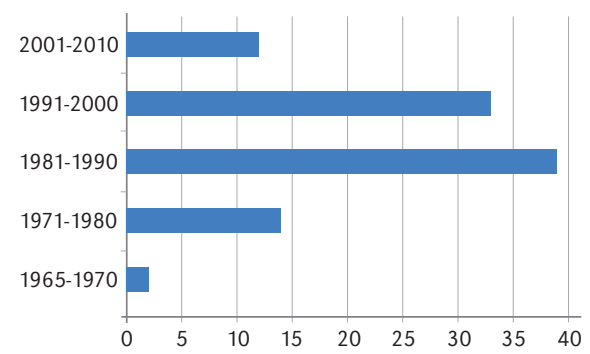

Figure 3. Period of migration from the Presheva Valley

Source: Data from survey conducted from July 17 until August 17, 2014 (the same applies to Figs. 4 and 5).

With similar intensity and for the same reasons as in the previous period, the migration of the population continues over the period 1991-2000, when 33\% of the total recorded migrants migrated towards Western European countries. The process of destruction of Tito's Yugoslavia led to conflicts and wars in Croatia, in Bosnia and finally, in Kosovo. Many Albanian youths migrated, mainly illegally, by deserting from the Yugoslav army, where, against their will, they would be engaged in a war against the Croats and Bosnians. A highlight of this period was the war of 1999, when many young people, together with their families from the refugee camps in Macedonia, went to many countries of Western Europe and further.

Migration of the population from the valley continued after the year 2000. During the period from 2001 to 2010 12\% of the total number of migrants migrated out of the valley. During this period, the failure to achieve a liberalization of the visa regime for Serbia with the majority of EU countries contributed to migration. During this period, we have the migration of entire families from the municipalities of Presheva and Bujanoci, primarily to Belgium, Sweden, France, the Netherlands, etc.

\section{Causes of migration}

Regarding the research question about the causes of migration, $52 \%$ of the respondents answered that they migrated to provide better living conditions (Fig. 4). Employment and higher incomes have enabled migrants to provide support for themselves, as well as the economic and social welfare of their families at home.

Out of the total number of respondents, $8 \%$ said that the purpose of emigration was to build a new house. War and its consequences have been the main reason for the migration of $16 \%$ of migrants from the valley. Analyzing and comparing the causes of migration with the period of migration appears to show that this category of migrants belongs to the period from 1991-2000. This is the period of disintegration of the former Yugoslavia, with several civil wars and conflicts which directly and indirectly resulted in the migration of the Albanian population, mostly younger people. The causes of migration at the beginning of this period were associated with the indirect consequences of wars and conflicts such as the inclusion of Albanian youth, against their will, in the wars in Croatia and Bosnia, which caused desertion and illegal emigration towards the countries of Europe. The direct effects of the war are those occurring during the armed conflict in Kosovo and the Presheva Valley, where, during NATO's bombing campaign on police and military targets, Albanian youth, but also entire Albanian families, illegally crossed the border to Macedonia and went to many countries in Europe.

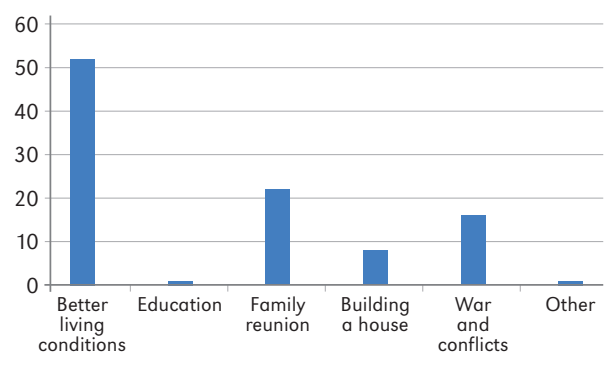

Figure 4. Causes of external migration from the Presheva Valley 
The emigration cycle usually begins with the migration of pioneer workers followed by a transition towards an increasing share of family members through family reunion. With $52 \%$ of labor migrants, the Presheva Valley is in the middle of the cycle. Comparing data about the causes of migration in the Presheva Valley with the countries of the region, we can see a very similar situation. In Serbia, $47 \%$ of migrants are labor migrants, in the Former Yugoslav Republic of Macedonia $43.7 \%$, while in Kosovo there are $46.4 \%$ labor migrants. With $22 \%$ of people that have migrated for family reunion, the Presheva Valley has 10\% more than in Serbia where just 12\% of people migrate for family reunion. In Kosovo $26.4 \%$ of people migrate for family reunion, in Albania 27\% of them while in the Former Yugoslav Republic of Macedonia 27.1\% (Kupiszewski et al. 2009). In the case of the Presheva Valley this category of respondents, in terms of age, mainly includes middle-generation migrants who have migrated to join their parents (the father takes his wife and children), and the last time family reunion is done is mostly through marriages between youth living abroad and those living at home. Only 1\% of migrants declared education as a reason for migration.

\section{Directions of migration}

After data processing from the survey regarding the research question on the country of migration, we saw that $60 \%$ of the Albanian population had migrated to Switzerland, so even these days the majority of the migrant population from the Valley go to this state (Fig. 5). The country with the second largest number of migrants is Germany with $17 \%$ of migrants, followed by Austria with $8 \%$, Sweden with $4 \%$, Norway with $2 \%$, France and United States with $1 \%$ and the others with $1 \%$. Comparing this data with migration data from Kosovo we can see that the direction of migration is almost the same. According to Mustafa et al (2007) most Kosovars live in Germany (39\%), Switzerland (23\%), Italy, Austria (6\%) the UK, Sweden (5\%) and the USA (Mustafa

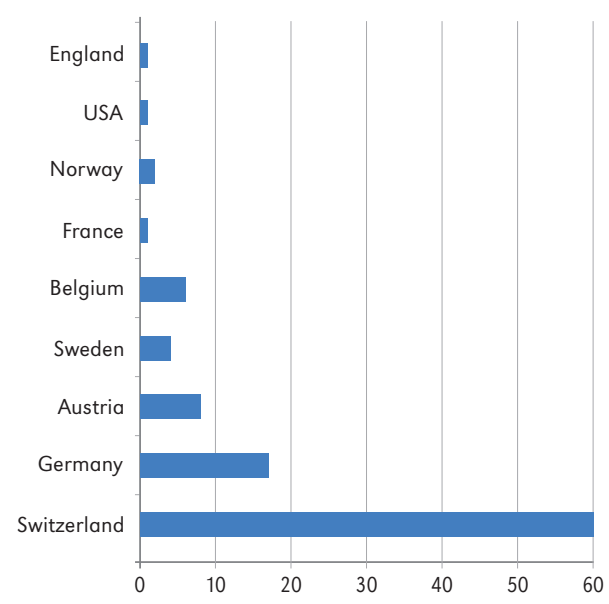

Figure 5. Migration by country of destination

et al 2007). This provides evidence that the process of migration from the Presheva Valley is very similar to that in Kosovo and it is related not to the same push and pull factors, but also to having the same ethnic structure of the population with a majority Albanian population.

Comparing the place of migration with the period of migration we can see that the earliest migrations are towards countries like Switzerland, Germany and Austria, and coincide with the period of the late 1960s and early 1970s and continue later, while in the Scandinavian countries, Belgium, France and other countries, with one possible exception, migration takes place after the 1990s.

Under economic, political, and psychological pressures and open violence during the 1990s, many Albanians from the Presheva Valley migrated abroad. This period ends with the armed conflict between local Albanians and the Serb forces in 2001. Thus, during this period the population which migrated abroad was increased from 5.7\% in 1991 to $21 \%$ in 2002.

The process of migration continues, and the long period of emigration makes it difficult to determine the definition of 'transiency' (Aničić \& Breznik 1978). This results from the fact that more than 40 years have passed since the beginning of the mass migration 
of the population that corresponds to the early 1970s until now, and from the 1990s many family members went to live with parents who work there, their children have grown up, been educated, employed and have married in foreign countries, creating new families. Immigrants from the Albanian-speaking area of former Yugoslavia have been exposed to stigmatization in public opinion and moreover their children have been subject to discrimination (Fibbi \& Truong 2015). Unlike the early immigrants, who were usually young unmarried men, the second generation including children of immigrants of the first period of emigration, especially the last generation that includes children born abroad, is fully integrated in all aspects of life.

\section{Benefits and consequences of migration}

Effects that have and that will occur in relation to the development of social and family life are direct or indirect, sustained or intermittent, short-term or long-term, positive or negative. The positive effects are observed mainly by the improving economic and social welfare of the population in the Presheva Valley, which has a family member with temporary work abroad. Incomes were invested in housing construction, agriculture and household equipment which have caused these families to reach higher living standards and social prestige. Through coordinated action with residents and local village communities, various infrastructure projects were implemented in the Presheva Valley which improved living conditions in the villages.

In the difficult economic and social situation that has prevailed in Serbia and the Presheva Valley after the 1990s, the remittances have been an important resource for the survival of many families in the Presheva Valley. This strong Diaspora in Europe also financially supported the war in Kosovo and the Presheva Valley and many families of the victims and fallen combatants.

Proper advantage has not so far been taken of the economic potential of the Valley
Diaspora. Different national contributions are the most common form of capital investment aimed to help families in the difficult economic situation, but failed to create jobs and generate economic development.

Among external migrants today there are many owners of construction companies and small businesses who wish to invest their capital. But the lack of political and economic stability, extreme bureaucracy in administration, and other barriers that appear if one wants to open a mini-business or industrial unit, have turned the region into an unfavorable environment for investment.

In addition, negative effects were and are diverse. They are demographic, social, cultur$\mathrm{al}$, etc. Since almost $25 \%$ of the population of Presheva Valley lives abroad and many of them belong to a young age group, this could have a negative effect on the age structure of the population of the Presheva Valley and produce a rapid decline in the total fertility rate which in the long term, combined with the sustained emigration of predominantly young persons, will lead to a reduction in the number of young, productive adults and an increase in older age groups.

Another negative effect is the abandonment of agriculture by creating the impression that countryside and agriculture have no prospects; that these activities have to be abandoned (Islami 1985). Therefore there is a strong belief among the young population that external migration is the only key available to improving the conditions of their social and economic welfare thus making them feel inferior and show no interest in education and employment, or even to avoid establishing families in the country of their birth.

Differences are also evident within social norms between the birthplace and the immigrant which cause problems and difficulties in adaptation in the new social environment. Language difficulties and the lack of other communication skills, cultural and religious differences, appear as a serious obstacle in the adaption and faster integration of new migrants in social life. Therefore for the greatest number of external migrants, $77 \%$ of them, 
cultural and social norms are still a major obstacle to their integration in the new social environment.

Access to services like housing, education and health should not only be seen as directly improving the migrant's position in the host country, but equally crucially should be seen as an investment in the migrant's human capital (De Palo et al. 2006). In last 20 years this is what is happening with Albanian migrants from the Presheva Valley.

Powerful integration of new generations of migrants in different European countries makes their feeling of origin slowly fade away, and enables them to show signs of assimilation. One of the many definitions of assimilation defines it as the attenuation of distinction based on ethnic origin (Alba \& Nee 2003). Many children borne abroad hardly speak Albanian, while embracing the lifestyle of European industrialized societies more readily they prefer to spend their holidays in the resorts of Mediterranean Europe, Asia, and South America rather than to come to their homeland (Ejupi 2013). This contributes to more physical and spiritual separation and increases the risk of faster assimilation.

\section{Conclusions}

Summing up all these results we conclude that external migration was more caused by push factors such as economic and social backwardness, a fragile political situation and wars (especially after the 1980s) which distinguish migrations from backward regions. What we can see from the research is that while in recent decades most of people from ex Yugoslavia have emigrated to Germany, in the case of the Presheva Valley the largest number of people have emigrated to Switzerland.

We did not identify any examples of highskilled migration ('brain-drain') during the empirical research, a phenomenon which is present and which intensified in Serbia especially after the 1990s. During the last few decades some important changes have occurred in terms of migration trends regarding the causes of migration. The number of people who migrate for reasons of family reunification, especially through marriage, has continually increased. These migrations are followed by different demographic, economic and political consequences. This can be illustrated by a decline in the number of pupils in primary and secondary education. Knowing the demographic development in the past, and identifying the causes and intensity of migration, it can be concluded that the mountainous parts of the region will be exposed to intensive processes of depopulation.

The decline in the population is also reflected in certain political consequences regarding the realization of the individual and collective rights of the Albanians. Although we didn't manage to provide precise data about the annual value of remittances, we think that they have played a positive role by providing for the survival and maintenance of social welfare, but without managing to become a generator of economic growth in the region.

\section{Acknowledgements}

This work is a part of a wider study of Presheva Valley financed by the Academy of Sciences and Art of Kosovo. The author would like to thank Academician Hivzi Islami for his helpful comments and suggestions which contributed greatly to this paper.

\section{Editors' note:}

Unless oth erwise stated, the sources of tables and figures are the authors', on the basis of their own research. 


\section{References}

Alba R., Nee V., 2003. Remaking the American mainstream: Assimiliation and Contemporary immigration. Cambridge, Mass.: Harvard University Press.

ANIČıČZ., BREZNIIK D., 1978. Neka metodološka pitanja popisa stanovništva 1981 i predlozi za njihovo rešavanje. Godišnji Sastanak Jugoslovenskog Statističkog Društva, Priština, 9.

Yugoslav Census of population 1971: MigraTIONS, DATA ON SETTLEMENTS AND MUNICIPALITIES, 1973. Belgrade: Federal Bureau of Statistics, pp. 291-321.

Çaro E., Van VisSen L.J.G., 2007. Migration in the Albania of the post 1990s: Triggered by postcommunist transformations and facilitator of sociodemographic changes. SEER: South East Europe Review for Labour and Social Affairs, vol. 10, no. 3, pp. 87-105.

De Palo D., Faini R., Venturini A., 2006. The social assimilation of immigrants. IZA Discussion Paper No. 2439.

EJuPI A., 2013. Lugina e Preshevës: studim kompleks gjeohapësinor. Presheva Valley - complex geospatial study, Prishtina: Akademia e Shkencave dhe e Arteve e Kosovës (ASHAK).

EJupI A., RamadanI I., 2016. Regional differentiation and the geopolitical and transboundary position of Presheva Valley. Miscellanea Geographica, vol. 20, no. 4, pp. 22-28.

Fassmann H., 2015. Migration in und aus Südosteuropa - Ein demographischer Überblick. Südosteuropa Mitteilungen, vol. 55, no. 1, pp. 6-22.

FIBBI R., TRUOng J., 2015. Parental involvement and educational success in Kosovar families in Switzerland. Comparative Migration Studies, vol. 3, no. 1, pp. 3-13.

Grečlć V., Petronijević V., Willis P., 2007. Strengthening cross-border cooperation in the Western Balkan regarding migration management
- Serbia (including Kosovo) and Republic of Montenegro [in:] V. Petronijević (ed.), Migration flows in Southeast Europe: A compendium of national perspectives, Belgrade: Grupa 484, pp. 77-107.

ISLAMI H., 2005. Demographic studies: 100 years of demographic development in Kosovo. Prishtina: Academy of Arts and Sciences of Kosovo.

IsLAMI H., 1984. O nekim metodološkim pitanja migracija. Sveske, no. 7-8. Sarajevo: Institut za proucavanje nacionalnih odnosa, pp. 171-176.

ISLAMI H., 2012. Aspekti etnik i migrimeve(Shqiptarët në rrjedhat e shpërnguljeve të dhunshme). Prishtina: Akademia e Shkencave dhe e Arteve e Kosovës (ASHAK).

IsLAMI H., EJUPI A., 2015. Popullsia dhe vendbanimet shqiptare të Luginës së Preshevës. Prishtina: Akademia e Shkencave dhe e Arteve e Kosovës (ASHAK).

Kahanec M., Zimmermann K.F., 2008. Migration and globalization: Challenges and perspectives for the research infrastructure. IZA Discussion Paper No. 3890, pp. 1-14.

Krasnićl M., Melik A., Kordić M., Zaumi A., 1963. Savremene društveno-geografske promene na Kosovu i Metohiji. Prishtina: Muzej Kosova i Metohije.

Kupiszewski M., Kicinger A., Kupiszewska D., Flinterman F.H., 2009. Labour migration patterns, policies and migration propensity in the Western Balkans. Budapest: The Central European Forum for Migration and Population Research (CEFMR).

Mustafa M., Kotorri M., Gashi P., Gashi A., DeMUKA V., 2007. Forum 2015: Diaspora and migration policies. Prishtina: Riinvest Institute.

SAuvy A., 1966. Theorie generale de la population, Vol. 2: La vie des population. Paris: Presses Universitaires de France.

VuKović D., 2005. Migration of the labour force from Serbia. Journal for Labor and Social Affairs in Eastern Europe, vol. 8, no. 4, pp. 139-150. 